\title{
HUBUNGANANTARA KEIKUTSERTAAN IBU HAMIL PADA PROGRAM PERENCANAAN PERSALINAN DAN PENCEGAHAN KOMPLIKASI (P4K) DENGAN KEJADIAN KOMPLIKASI PERSALINAN DIWILAYAH KERJA PUSKESMAS WARUNGGUNUNG KABUPATEN LEBAK 2016
}

\author{
*Nintinjri Husnida, *NaniYuningsih \\ E-mail : nintin_gh@yahoo.co.id
}

\begin{abstract}
Abstrak
Tingginya angka kematian ibu setiap tahun dan semakin meningkat, sehingga perlunya melihat hubungan antara keikutsertaan ibu hamil pada program perencanaan persalinan dan pencegahan komplikasi ( $\mathrm{P} 4 \mathrm{~K})$ dengan kejadian komplikasi persalinan di Wilayah kerja Puskemas Warunggunung Kabupaten Lebak 2016. Berdasarkan gambaran tentang tingginya Angka kematian ibu di Provinsi Banten, maka dirumuskan masalah penelitian bagaimanakah hubungan antara keikutsertaan ibu hamil pada program perencanaan persalinan dan pencegahan komplikasi (P4K) dengan kejadian komplikasi persalinan, sedangkan hipotesis yang dirumuskan terdapat hubungan antara keikutsertaan ibu hamil pada program perencanaan persalinan dan pencegahan komplikasi (P4K) dengan kejadian komplikasi persalinan.

Penelitian ini menggunakan metode kuantitatif dengan studi kohort dan menggunakan kuesioner. Jumlah sampel yang digunakan 48 responden, dengan total populasi. Data penelitian diambil secara primer menggunakan kuesioner. Analisis data untuk mengetahui hubungan antar variabel menggunakan Chi-Square.

Dari hasil penelitian secara univariat menunjukkan jumlah ibu yang tidak memanfaatkan P4K sebesar 31,3\%, kejadian komplikasi sebesar 33,3\%. Dari hasil uji bivariat didapatkan bahwa ada hubungan yang signifikan antara keikutsertaan ibu hamil pada program perencanaan persalinan dan pencegahan komplikasi (P4K) dengan kejadian komplikasi di wilayah kerja Puskemas Warunggunung Kabupaten Lebak 2016 dan nilai 0,008 (p $<\alpha)$ dapat diartikan bahwaada hubungan ibu hamil yang mengikuti P4K dengan kejadian komplikasi.

Dapat disimpulkan bahwa Terdapat hubungan signifikan antara pemanfaatan $\mathrm{P} 4 \mathrm{~K}$ pada ibu hamil dengan kejadian komplikasi persalinan
\end{abstract}

Kata kunci :P4K, Pencegahan komplikasi kehamilan dan persalinan

*) Dosen Jurusan Kebidanan Poltekkes Kemenkes Banten 


\section{Pendahuluan}

Kondisi kesehatan ibu dan bayi di Indonesia saat ini masih sangat penting untuk ditingkatkan serta mendapat perhatian khusus.Angka kematian ibu dan angka kematian bayi di Indonesia masih sangat tinggi.Menurut survei demografi dan kesehatan Indonesia tahun 2012 angka kematian ibu adalah 359 per 100.000 kelahiran hidup. Angka tersebut masih jauh dari target yang di harapkan. Angka kematian ibu di provinsi banten pada tahun 2013 berdasarkan laporan dari Kabupaten sebanyak 216/100.000 kelahiran hidup sedangkan pada tahun 2014 AKI sebanyak 230/100.000 kelahiran hidup dan penyebab kematian ibu terutama adalah perdarahan, eklampsia/ preeklamsia, dan infeksi . 1,2

Hal tersebut di atas disebabkan oleh penyebab kematian ibu yang kompleks, menyangkut aspek medis yang harus ditangani oleh tenaga kesehatan. Sedangkan penyebab non medis yang dapat mempengaruhi penyebab kematian ibu seperti status perempuan, sosial budaya, pendidikan, ekonomi, geografis,transportasi, tingkat pengetahuan dan sebagainya yang memerlukan keterlibatan lintas sektor dalam penanganannya. $^{3}$

Wanita hamil merupakan salah satu kelompok golongan yang rentan menghadapi masalah kematian serta bayi yang dikandungnya. Perencanaan persalinan dan pencegahan komplikasi merupakan upaya untuk mencegah kompliaksi yang berujung pada kematian . Salah satu upaya pencegahan tersebut dapat melalui program perencanaan persalinan dan pencegahan komplikasi (P4K).

Upaya penurunan kematian ibu dan bayi, dapat dilakukan dengan peningkatan cakupan dan kualitas pelayanan kesehatan ibu dan anak. Salah satu upaya yang dilakukan adalah mendekatkan jangkauan pelayanan kesehatan kepada masyarakat melalui Program, perencanaan, persalinan dan pencegahan komplikasi (P4K). Melalui kegiatan $\mathrm{P} 4 \mathrm{~K}$, ibu, keluarga dan masyarakat diberdayakan untuk meningkatkan kemandirian, antara lain dengan membuat perencanaan persalinan danmengetahui tanda-tanda bahaya pada kehamilan, persalinan dan nifas serta memanfaatkan Buku KIA. ${ }^{6}$

Kabupaten Lebak khususnya di wilayah kerja puskesmas Warunggunung memiliki karakteristik penduduk beragam dan mampu menindaklanjuti program ini melalui pelatihan dan sosialisasi $\mathrm{P} 4 \mathrm{~K}$ secara rutin setiap tahun, namun dalam implementasinya belum dapat dilaksanakan secara optimal. Hal ini didukung kurangnya pengetahuan masyarakat mengenai pentingnya $\mathrm{P} 4 \mathrm{~K}$. Kurangnya pengetahuan mengenai hal tersebut kemungkinan bisa dikarenakan informasi yang dijelaskan tenaga kesehatan belum secara terperinci dan dimengerti oleh ibu hamil , terutama ibu 
hamil dengan pendidikan yang rendah, umur yang relatif muda atau tua, ataupun pengalaman hamil dan jumlah anak yang pernah dilahirkan oleh ibu (jumlah paritas). Program perencanaan persalinan dan pencegahan komplikasi adalah upaya untuk mencegah komplikasi, sehingga untuk mewujudkan sistem tersebut maka dapat dilakukan dengan melibatkan berbagai lintas sektoral dengan unsur -unsur yang terdapat didalamnya . Unsur tersebut berisi tentang perencanaan persalinan yang meliputi rencana penolong persalinan, tempat persalinan, sarana transportasi, biaya persalinan, pendamping persalinan dan calon donor darah.Pertemuan ini dapat dilakukan di fasilitas kesehatan atau di rumah ibu hamil atau di posyandu. ${ }^{6}$

\section{Metode Penelitian}

Subjek penelitian adalah ibu hamil yang memenuhi criteria inklusi dan eksklusi serta bersedia mengikuti penelitian dengan mengisi lembar persetujuan (informed consent). Populasi target dalam penelitian ini adalah seluruh ibu hamil baik yang mengikuti program $\mathrm{P} 4 \mathrm{~K}$ maupun yang tidak mengikuti P4K dan tersebar di 6 desa wilayah kerja puskesmas warunggunung. Populasi terjangkau dalam penelitian ini adalah Ibu hamil yang melahirkan pada bulan Agustus 2016.

Penelitian ini tidak menggunakan teknik sampling, namun menggunakan total populasi terhadap ibu hamil yang memenuhi criteria inklusi dan tidak termasuk criteria eksklusi sejumlah 48 orang berdasarkan data yang terdapat di Puskesmas.

Penelitian ini adalah studi kohort yang menjelaskan hubungan antara keikutsertaan ibu hamil pada P4K dengan kejadian komplikasi persalinan di wilayah kerja Puskesmas Warunggunung Kabupaten Lebak Tahun 2016

Variabel pada penelitian ini terdiri dari 3 variabel yang akan diukur: Variabel bebas, variable terikat, dan variable perancu. Adapun variabel yang akan diteliti dalam penelitian ini adalah: Variabel bebas (independent variable) yaitu ibu hamil yang ikut serta pada P4K (X1) dan ibu hamil yang tidak ikut serta pada P4K (X2). Dan Variabel terikat (dependent variable) yaitu komplikasi kehamilan dan persalinan (Y).

\section{Hasil}

Tabel 1

Distribusi Frekuensi Ibu Hamil Berdasarkan Paritas

\begin{tabular}{ccc}
\hline Paritas & F & $\%$ \\
\hline Tinggi & 17 & 35.4 \\
Rendah & 31 & 64.4 \\
Jumlah & 48 & 100 \\
\hline
\end{tabular}

Tabel 1 menunjukan hasil dari 48 responden terdapat 17 orang $(35,4 \%)$ adalah paritas tinggi 
Tabel 2

Distribusi Frekuensi Ibu Hamil Berdasarkan Usia

\begin{tabular}{ccc}
\hline Usia & F & $\%$ \\
\hline Beresiko & 12 & 25.0 \\
Tidak & 36 & 75.0 \\
Jumlah & 48 & 100 \\
\hline
\end{tabular}

Tabel 2 menunjukan hasil dari 48 responden terdapat 12 orang $(25.0 \%)$ adalah usia beresiko.

Tabel3

Distribusi Frekuensi Ibu Hamil Berdasarkan Pendidikan

\begin{tabular}{ccc}
\hline Pendidikan & F & $\%$ \\
\hline Rendah & 34 & 70.8 \\
Tinggi & 14 & 29.2 \\
Jumlah & 48 & 100 \\
\hline
\end{tabular}

Berdasarkan tabel 3 didapatkan hasil dari 48 responden sebagain besar responden berpendidikan rendah sejumlah $34(70.8 \%)$.

Tabel 4

Distribusi Frekuensi Ibu Bersalin Berdasarkan Kejadian Komplikasi

\begin{tabular}{ccc}
\hline $\begin{array}{c}\text { Kejadian } \\
\text { Komplikasi }\end{array}$ & $\mathrm{F}$ & $\%$ \\
\hline Ya & 6 & 12.5 \\
Tidak & 42 & $87.5 \%$ \\
Jumlah & 161 & 100 \\
\hline
\end{tabular}

Berdasarkan tabel 4 diketahui bahwa masih terdapat ibu bersalin yang mengalami komplikasi persalinan sebesar $12.5 \%$.
Tabel 5

Distribusi Frekuensi ibu hamil Berdasarkan Keikutsertaan P4K

\begin{tabular}{ccc}
\hline $\begin{array}{c}\text { Keikutsertaan } \\
\text { P4K }\end{array}$ & F & $\%$ \\
\hline Tidak & 15 & 31.3 \\
Ikut & 33 & 68.8 \\
Jumlah & 48 & 100 \\
\hline
\end{tabular}

Berdasarkan tabel 5 diketahui bahwa masih banyak ibu hamil yang tidak ikut P4K sebesar 31.3

Tabel 6

Hubungan keikutsertaan ibu hamilpada program perencanaan persalinan dan pencegahan komplikasi ( $\mathrm{P} 4 \mathrm{~K})$ dengan kejadian komplikasi persalinan

\begin{tabular}{|l|c|c|c|l|}
\hline \multirow{2}{*}{$\begin{array}{l}\text { Keikutse } \\
\text { rtaan }\end{array}$} & \multicolumn{2}{|c|}{ Komplikasi } & Jumlah & P \\
\cline { 2 - 4 } Total & Tidak & Ya & Value \\
\hline Tidak & $\begin{array}{c}10 \\
\text { Ikut }\end{array}$ & $\begin{array}{c}5 \\
(66,7 \%)\end{array}$ & $\begin{array}{c}15 \\
(33.3 \%)\end{array}$ & \\
\hline Ikut & $\left.\begin{array}{c}32 \\
(97.0 \%)\end{array}\right)$ & 1 & 33 & \\
& $(3.0 \%)$ & $(100 \%)$ & 0,008 \\
\cline { 1 - 4 } Total & $\begin{array}{c}42 \\
(87.5)\end{array}$ & $\begin{array}{c}6 \\
(12,5)\end{array}$ & $\begin{array}{c}48 \\
(100 \%)\end{array}$ & \\
\hline
\end{tabular}

Berdasarkan tabel silang 6

menunjukkan bahwa responden yang ikut serta pada P4K mengalami komplikasi lebih sedikit (3.0\%) daripada responden yang tidak ikut P4K mengalami komplikasi yaitu $33.3 \%$. Dengan nilai $p$ sebesar $0,008(p<\alpha)$, berarti menolak $\mathrm{H} 0$, yang artinya terdapat hubungan signifikan antara keikutsertaan ibu hamil dalam P4K dengan kejadian komplikasi persalinan. 


\section{Pembahasan}

Karakteristik responden yang diteliti adalah paritas, usia, pendidikan, keikutsertaan P4K dan kejadian komplikasi. Dalam pengolahan data, paritas dibedakan menjadi 2 kategori yaitu tinggi dengan nilai jumlah paritas $\geq 3$ dan rendah dengan paritas < 3. Sedangkan variable usia dibedakan beresiko apabila usia ibu $<20$ tahun dan Lebih dari 35 tahun dan tidak beresiko apabila usia ibu antara 20 - 35 tahun. Variabel pendidikan dibedakan dalam kategori rendah apabila responden minimal tamat SMP kebawah dan tinggi apabila responden minimal tamat SMA keatas.

Paritas adalah jumlah janin dengan berat badan lebih dari 500 gram atau lebih, yang pernah dilahirkan, hidup atau mati. Bila berat badan tidak diketahui maka dipakai batas umur kehamilannya 24 minggu. Sueheilif Paritas adalah status seorang wanita sehubungan dengan jumlah anak yang pernah dilahirkannya. Ibuyang baru pertama kali hamil merupakan hal yang sangat baru sehingga termotivasi dalam memeriksakan kehamilannya ke tenaga kesehatan. Sebaliknya ibu yang sudah pernah melahirkan lebih dari satu orang mempunyai anggapan bahwa ia sudah berpengalaman sehingga tidak termotivasi untuk memeriksakan kehamilannya. $^{11}$
Paritas menunjukkan jumlah anak yang pernah dilahirkan oleh seorang wanita. Paritas adalah banyaknya kelahiran hidup yang dipunyai oleh seorang wanita wanita. Paritas merupakan faktor penting dalam menentukan nasib ibu dan janin baik selama kehamilan maupun selama persalinan. ${ }^{15}$

Berdasarkan teori paritas adalah jumlah anak yang dilahirkan oleh seorang wanita. Semakin sering seorang wanita melahirkan maka akan semakin tinggi pula wanita tersebut berpeluang mengalami komplikasi pada saat kehamilan dan persalinan. Pada hasil didapatkan responden dengan paritas tinggi berjumlah $35.4 \%$. Dengan adanya hasil tersebut maka memungkin ibu hamil dengan paritas tinggi mengalami komplikasi, karena terlalu sering akan menyebabkan seorang ibu belum cukup untuk memulihkan kondisi tubuhnya setelah melahirkan. Hal ini merupakan salah satu faktor penyebab kelemahan dan kematian ibu serta bayi yang dilahirkan, bahwa risiko reproduksi dapat ditekan apabila frekuensi melahirkan tidak terlalu banyak.

Terdapatnya hasil dengan paritas tinggi menggambarkan kurang nya kesadaran ibu atau pasangan untuk mendukung upaya KB terutama dengan penggunaan alat kontrasepsi yang bersifat jangka panjang. Dengan penggunaan alat kontrasepsi jangka panjang maka akan mempekecil peluang ibu untuk hamil dan 
terhindar komplikasi pada kehamilan dan persalinan.

Usia reproduktif ibu untuk hamil dan melahirkan adalah antara 20 tahun - 35 tahun. Dalam hasil ini masih terdapat ibu hamil dengan usia yang beresiko, hal ini dimungkinkan karena kurangnya kesadaran dari masyarakat tentang bahaya kehamilan yang terjadi dimasa reproduksi yang kurang dari 20 tahun dan kurangnya kesadaran juga oleh mayarakat PUS untuk ber KB diatas usia 35 tahun.

Hasil ini sejalan dengan teori anonym yang dikutip oleh Yuli Kusumawati menyatakan bahwa masih banyak terjadi perkawinan, kehamilan dn persalinan diluar kurun waktu reproduksi yang sehat, terutama pada usia muda. Umur, tinggi badan dan berat badan wanita merupakan risiko preeclampsia.Wanita berumur 35 tahun atau lebih meningkat risikonya dalam masalah-masalah seperti darah tinggi, gestasional diabetes dan komplikasi selama persalinan. $^{17}$

Penelitian ini sejalan dengan penelitian dari Dirbadiyah dalam mariani (2009) dengan sikap ibu yang melakukan persalinan dengan dukun bayi bahwa pendidikan berhubungan dengan pemilihan penolong persalinan. ${ }^{4}$

Berdasarkan hasil distribusi banyaknya responden dengan pendidikan rendah maka dimungkinkan masih terdapat kurangnya kesadaran ibu untuk ikut serta pada P4K. Hal ini dikarenakan terkait dengan pendidikan yang rendah maka pengetahuan yang dimiliki juga kurang dalam hal ini yaitu tentang $\mathrm{p} 4 \mathrm{k}$ atau dapat pula dimungkinkan isi dari $\mathrm{P} 4 \mathrm{~K}$ seperti taksiran persalinan, biaya persalinan, penolong persalinan dan lain sebagainya merupakan hal yang sudah tidak asing bagi ibu hamil karena mereka sebenarnya sudah sering mendapat informasi tersebut hanya saja mereka tidak paham bahwa informasi tersebut adalah $\mathrm{P} 4 \mathrm{~K}$ sehingga kadang kala mereka tidak mempersiapkannya sejak awal kehamilan.

Hasil ini sesuai dengan pendapat dari Sukmadinata (2003) dan Soekanto(2002) bahwa seseorang yang mempunyai banyak sumber informasi akan mempunyai pengetahuan yang luas pula. Walaupun kebanyakan responden menjawab belum pernah dapat informasi tentang $\mathrm{P} 4 \mathrm{~K}$ tetapi ada kemungkinan mereka telahmendapat informasi yang berhubungan dengan $\mathrm{P} 4 \mathrm{~K}$ sehingga mereka dapat menjawab pertanyaan yang berhubungan dengan P4K. Penelitian ini juga sejalan dengan penelitian Latifa Hesti (2009) bahwa pendidikan berpengaruh terhadap niat ibu hamil bersalin dengan tenaga kesehatan. ${ }^{20,21}$

Komplikasi kehamilan adalah komplikasi yang terjadi hanya pada saat kehamilan. $^{22}$ Sedangkan komplikasi persalinan merupakan suatu kegawatdruratan obstetrik yang paling 
sering menyebabkan kematian pada ibu melahirkan. ${ }^{23}$

Hasil penelitian ini masih menunjukkan terdapatnya komplikasi yang terjadi pada ibu hamil sebesar $12.5 \%$. Hal ini dimungkinkan karena masih teradapat nya ibu hamil yang belum mengikuti P4K secara optimal serta pengaruh budaya dan juga kesadaran melakukan pemeriksaan kehamilan bukan hanya di nakes tetapi juga di dukun, selain itu hal ini juga didukung oleh data masih banyak ibu hamil dengan paritas tinggi dan usia beresiko untuk hamil.

Dari hasil penelitian ini didapatkan ibu hamil yang tidak mengikuti program sebesar $31.3 \%$, angka ini lebih kecil dari ibu hamil yang mengikuti program, sehingga diasumsikan bahwa dengan banyaknya ibu hamil yang mengikuti program $\mathrm{P} 4 \mathrm{~K}$ akan kecil peluang nya mengalami komplikasi pada saat kehamilan dan persalinan.

Hal ini sesuai dengan teori tentang tujuan $\mathrm{p} 4 \mathrm{k}$.Tujuan $\mathrm{P} 4 \mathrm{~K}$ adalah yaitu Meningkatkan cakupan dan mutu pelayanan bagi ibu hamil dan bayi baru lahir melalui peningkatan peran aktif keluarga dan masyarakat dalam merencanakan persalinan yang aman dan persiapan menghadapi komplikasi dan tanda bahaya kebidanan bagi ibu sehingga melahirkan bayi yang sehat. ${ }^{6}$
Berdasarkan tabel silang 6 diketahui bahwa nilai $p$ pada analisis bivariat dengan uji chi square adalah $0,008(\mathrm{p}<\alpha)$ dapat diartikan bahwa ada hubungan ibu hamil yang mengikuti P4K dengan kejadian komplikasi. Sesuai dengan amanah yang terdapat pada buku KIA bahwa keikutsertaan ibu pada P4K yang meliputi perencanaan penolong persalinan, perencanaan tempat persalinan, perencanaan biaya persalinan, perencanaan transportasi persalinan, perencanaan pendamping persalinan, perencanaan pendonor darah dapat menghindari komplikasi persalinan.

Secara terperinci komponen dari keiukutsertaan ibu hamil pada $\mathrm{P} 4 \mathrm{~K}$ sejalan dengan Fibriana yang dikutip oleh afdhal bahwa pemilihan penolong persalinan bukan tenaga kesehatan berhubungan dengan kejadian komplikasi dan berisiko 3.7 kali lebih besar mengalami kematian maternal daripada ibu yang memilih tenaga kesehatan sebagai penolong persalinan, dimana kematian maternal $95 \%$ disebabkan karena komplikasi.

Berdasarkan nilai risiko kohort terjadi komplikasi 11 yang berarti bahwa ibu hamil yang tidak mengikuti P4K beresiko 11 kali lebih besar untuk terjadi komplikasi bila dibandingkan dengan ibu hamil yang ikut P4K.

Hasil tersebut menggambarkan bahwa ibu yang tidak mengikuti $\mathrm{P} 4 \mathrm{~K}$ sangat erat 
sekali memberikan dampak pada kejadian komplikasi.Hal tersebut dikarenakan ibu dapat mengalami komplikasi persalinan dimungkinkan karena kurang nya persiapan di awal kehamilan yang mencakup komponen - komponen keikutsertaan P4K. Kurangnya persiapan tersebut dimungkinkan karena banyak faktor yang menyertai seperti biaya, paritas, pengetahuan dan pendidikan , motivasi dan dukungan keluarga, atau faktor risiko yang dimiliki ibu sendiri dll. Hal ini juga diperkuat oleh penelitian afdhal dkk bahwa komponen perencanaan persalinan mempengaruhi kejadian komplikasi . ${ }^{12}$

\section{Simpulan}

Karakteristik subjek penelitian yaitu kejadian komplikasi persalinan sebesar $12.5 \%$ dan keikutsertaan P4K $31.3 \%$ adalah ibu hamil yang tidak memanfaatkan P4K

Terdapat hubungan yang signifikan antara pemanfaatan $\mathrm{P} 4 \mathrm{~K}$ pada ibu hamil dengan kejadian komplikasi persalinan

\section{Daftar Pustaka}

1. SDKI. Survei Demogravi dan kesehatan Indonesia. Jakarta. 2010

2. Dinkes Propinsi. Profil kesehatan propinsi Banten. Dinas Kesehatan Serang. 2014.
3. Laporan MDG's : Mari kita suarakan MDG's. Bappenas. Jakarta. 2008

4. Djatiningsih M, Wahyuningsih NTA. Gambaran tingkat pengetahuan Ibu hamil tentang persiapan menjelang persalinan di Rumah Sakit Panti Wilasa “Citarum” Semarang. Diunduh tanggal 21 April 2016. Diakses di http:// Jurnal kebidanan panti wilasa, Vol 2 No. 1 Oktober 2011.

5. Notoatmojo S. Pengembangan sumber daya manusia. Rineka Cipta.Jakarta. 2003.

6. Departemen Kesehatan RI. Pedoman Perencanaan Persalinan dan pencegahan komplikasi (P4K) dengan Stiker. Jakarta: Departemen Kesehatan RI. 2009

7. Dwijayanti Putri. Analisis Implementasi Program Perencanaan Persalinan dan pencegahan Komplikasi (p4k) oleh bidan desa Di Kabupaten Demak. di unduh tanggal 21 April 2016.

Diakses di http://ejournals1.undip.ac.id/ index.php/jkm.

8. Kementerian Kesehatan RI. Buku Kesehatan Ibu dan Anak. Jakarta; 
Kementerian Kesehatan dan JICA. 2015

9. Notoatmodjo S. Ilmu prilaku. Jakarta; Rineka Cipta. 2010

10. Manuaba IBG. Ilmu Kebidanan, Penyakit Kandungan dan KB untuk pendidikan bidan. Jakarta; EGC. 2010

11. Wiknjosastro dkk. Buku acuan Nasional Pelayanan kesehatan Maternal \& Neonatal.Jakarta; Yayasan Bina Pustaka sarwono Prawirohardjo. 2007

12. Afdhal dkk. Faktor risiko perencanaan persalinan terhadap kejadian komplikasi persalinan di kabupaten pinrang tahun 2012. di unduh tanggal 25 November 2016. Di akses diwww.repository.unhas.ac.id/bitsream /handle/123456789/4295/MUH.AFDH AL_k11109312.pdf?sequence $=1$.

13. Notoatmodjo, Soekidjo.Metodologi Penelitian Kesehatan. Rineka Cipta. Jakarta. 2010.

14. Dahlan, Muhammad Sopiudin. Statistik Untuk Kedokteran dan Kesehatan. Salemba Medika. Jakarta. 2011.
15. Bkkbn. Gender dalam kesehatan Reproduksi. 2009

16. Wijono, D. Manajemen kesehatan Ibu dan Anak. Duta prima Airlangga. Surabaya. 2008

17. Kusmawati Y. Faktor-faktor risiko yang berpengaruh terhadap persalinan dengan tindakan. Tesis program pascasarjana program pascasarjana universitas diponegoro, semarang . 2006. Di unduh tanggal 25 November $2016 . \quad$ Diakses di www.eprints.ac.id/15334/1/1Tesis_Yul i_Kusumawati,pdf.

18. Edyanti DB dan Indawati R, Faktor pada Ibu yang berhubungan dengan kejadian komplikasi kebidanan, Departemen Biostatistika dan kependudukan fakultas kesehatan masyarakat universitas airlangga 2014. Di unduh tanggal 25 November 2016 .Diakses diwww.journal.unair.ac.id/faktor-padaibu-yang-berhubungan-dengankejadian-article-8333-media-40category-3.html.

19. Wawan, Dewi. Teori dan pengukuran pengetahuan, sikap dan perilaku manusia. Nuha Medika.Yogyakarta. 2011 
20. Sukmadinata, N. Landasan Psikologi Proses Pendidikan. Remaja Rosdakarya Offset. Bandung. 2003.

21. Soekanto, S. Sosiologi Suatu Pengantar Edisi Baru Cetakan 34. Raja Gravindo Persada. Jakarta. 2002.

22. Retnowati I \& Astuti AD jurnal kebidanan, Vol II, No. 02 Desember 2010 Hubungan penerapan program perencanaan persalinan dan penceahan komplikasi (P4K) oleh Ibu hamil dengan upaya pencegahan komplikasi kehamilan di puskesmas sidorejo kidul salatiga. Diunduh pada tanggal 25 November 2016. Di akses www.journal.stikeseub.ac.id/index.php/ jkeb/article/view/81

23. Misar Y, masni dan Zulkifli A, faktor risiko komplikasi persalinan pada ibu melahirkan di kabupaten gorontalo utara Tahun 2012. Diunduh tanggal 25 November $2016 . \quad$ Diakses diwww.pasca.unhas.ac.id/jurnal/files/0 32f3fbb5039c51e91e590ocobbfda22.p df 